Miloš Božović ${ }^{1}$

JEL: F31, G12

Miloš Talijan²

DOI: 10.5937/industrija43-9109

UDC: 339.743

Original Scientific Paper

\title{
The anomalous forward premium of EUR/RSD exchange rate ${ }^{3}$
}

Article history:

Received: 22 September 2015

Sent for revision: 21 October 2015

Received in revised form: 10 December 2015

Accepted: 10 December 2015

Available online: 30 December 2015

\begin{abstract}
Theoretically, exchange rate fluctuations should be positively related to interest-rate differential. This paper empirically examines whether such a relationship holds between EUR/RSD exchange rate and the corresponding interbank interest rates. Estimates on daily data between 2008 and 2015 obtained from a linear regression model indicate that this relationship is in fact negative, consistent with the forward premium anomaly. The result persists over different time horizons. The exchange-rate predictability builds over time. The uncovered interest-rate parity does not hold.
\end{abstract}

Keywords: Exchange Rate, Interest-Rate Differential, Forward Premium, Predictability, Fundamentals

\section{Anomalna forvard premija kursa evra}

Apstrakt: Teorijski posmatrano, fluktuacije $u$ valutnim kursevima trebalo bi da zavise pozitivno od kamatnog diferencijala. $U$ ovom radu se empirijski ispituje da li ovakva veza postoji između kursa EUR/RSD i odgovarajućih kamatnih stopa na međubankarskom tržištu. Ocene dobijene na osnovu modela linearne regresije, na dnevnim podacima u periodu između 2008. i 2015. godine, ukazuju na to da je pomenuta veza zapravo negativna, saglasno anomaliji forvard premije. Rezultat opstaje na različitim vremenskim

\footnotetext{
${ }^{1}$ University of Belgrade, Faculty of Economics, milosbozovic@ekof.bg.ac.rs

${ }^{2}$ Center for Investments and Finance, Belgrade, Serbia.

3 This paper is a part of research projects number $\mathrm{OH} 179005$ financed by the Ministry of Science and Technological Development of the Republic of Serbia.
} 
Božović M., Talijan M.: The anomalous forward premium of EUR/RSD exchange rate

horizontima. Predvidivost kursa se akumulira vremenom. Nepokriveni kamatni paritet ne važi.

Ključne reči: valutni kurs, kamatni diferencijal, forvard premija, predvidivost, fundamenti

\section{Introduction}

In general, exchange rate fluctuations are difficult to predict. Meese \& Rogoff (1983a,b; 1988) were among the first to show that a naive random walk model outperforms all structural counterparts that have a firm theoretical ground. Exchange rates thus seem to be unrelated to their macroeconomic or financial fundamentals, such as interest rates, inflation, money supply or real income. These findings were revisited and confirmed by many authors since, using updated data and different econometric approaches. ${ }^{4}$ Engel \& West (2005) provide a theoretical analysis of this paradox. Rossi (2013) provides a critical overview of the literature on exchange rate forecasting in general and empirically illustrates recent methodologies and various proposed fundamentals.

A related strand of literature shows that exchange rate changes are negatively associated with interest-rate differentials, i.e. they tend to move in direction opposite to the one predicted by both theory and economic intuition. Empirical evidence of this phenomenon was presented by Hodrick $(1987,2000)$, Engel (1996), Meredith \& Chinn (1998), and many authors since. This so-called Forward Premium Puzzle (or Forward Premium Anomaly) has been documented, in one way or another, over different observation periods and across many currency pairs. The robustness of the anomaly makes it one of the most persistent puzzles in financial economics. Over the past two decades, it instigated a copious amount of research papers that suggested possible explanations, albeit with a limited success. Wu \& Zhang (1996) and Bansal \& Dahlquist (2000) suggest that the anomaly may be confined to developed economies.

This paper examines the relationship between the exchange rate of Euro (EUR) and Serbian Dinar (RSD) on one hand, and the corresponding interestrate differential on the other hand. We use daily observations of EUR/RSD exchange rate and interbank interest rates (BELIBOR and EURIBOR) during the 2008-2015 period. The exchange rate has either insignificant or negative relationship with the interest-rate differential, which is overall consistent with the Forward Premium Puzzle. The uncovered interest-rate parity hypothesis is resoundingly rejected. These results hold over different time horizons. The

\footnotetext{
${ }^{4}$ See, for instance, Cheung et al. (2003), Boudoukh et al. (2013) and the references cited therein.
} 
predictability of EUR/RSD exchange rate by the interest-rate differential tends to build over time.

The remainder of this paper is organised as follows. The following subsections provide more formal theoretical background for the Forward Premium Puzzle, as well as possible explanations provided by the literature. Section 2 describes the data, construction of the variables, and the methodology. Section 3 presents and analyses the results. Concluding remarks are given in Section 4.

\subsection{Theoretical Background}

Let $S_{t}$ be the spot exchange rate at time $t$, and $F_{t, T}$ be the forward rate at time $t$ for an exchange of currencies that occurs at time $T$. Under rational expectations,

$$
F_{t, T}=\mathbb{E}_{t}\left(S_{T}\right),
$$

where $\mathbb{E}_{t}(\cdot)$ denotes expected value conditionally on the information available at time $t$. In the absence of arbitrage, the covered interest-rate parity must hold:

$$
F_{t, T}=S_{t} \frac{B_{t, T}^{*}}{B_{t, T}}
$$

where $B_{t, T}$ and $B_{t, T}^{*}$ denote domestic and foreign discount factors, respectively. Under continuous compounding, the discount factors can be written as

$$
B_{t, T}=e^{-r_{t, T}(T-t)}
$$

and

$$
B_{t, T}^{*}=e^{-r_{t, T}^{*}(T-t)},
$$

where $r_{t, T}$ and $r_{t, T}^{*}$ are annualised domestic and foreign discount rates, respectively. By combining equations (2)-(4), we get:

$$
F_{t, T}=S_{t} e^{\left(r_{t, T}-r_{t, T}^{*}\right)(T-t)}
$$

Taking logarithms of both sides of equation (5) then gives: 


$$
f_{t, T}=s_{t}+\left(r_{t, T}-r_{t, T}^{*}\right)(T-t),
$$

where $f_{t, T}=\ln F_{t, T}$ and $s_{t}=\ln S_{t}$. A standard way of testing the rational expectation hypothesis given by equation (1) is to run the following regression:

$$
s_{T}-s_{t}=\alpha+\beta\left(r_{t, T}-r_{t, T}^{*}\right)(T-t)+\varepsilon_{t, T},
$$

where the constant $\alpha$ takes into account a possible Itô term, ${ }^{5}$ while the errors $\varepsilon_{t, T}$ satisfy the usual assumptions of a linear model.

Under uncovered interest rate parity (UIP), $\beta$ should be equal to one. In other words, currencies with lower interest rates should appreciate, and currencies with higher interest rates should depreciate. At any point in time, the rate of this appreciation/depreciation should be proportional to the interest-rate differential $r_{t, T}-r_{t, T}^{*}$. The hypothesis that $\beta=1$ is typically rejected. ${ }^{6}$ However, the Forward Premium Puzzle is an empirical anomaly that one also commonly finds a negative $\beta$. This means that the exchange rate moves in direction opposite to the one predicted by the interest-rate differential: if $r_{t, T}>r_{t, T}^{*}$, we usually observe $s_{T}<s_{t}$, while the theory predicts that $s_{T}>s_{t}$ on average. In other words, the forward premium $f_{t, T}-s_{t}$ is predictable on average and has a systematic bias. For instance, Boudoukh et al. (2013) show that changes in annual exchange rates of G10 currencies with respect to USD all have a negative regression coefficient that corresponds to the interest-rate differential. On a monthly overlapping basis, the null hypothesis that $\beta=1$ can be strongly rejected for seven out of nine currency pairs. Mengistu (2014) uses data from partially dollarized countries with higher and more volatile inflation rate, and finds that UIP also does not hold in these cases, showing strong evidence of a Forward Premium Puzzle.

\subsection{Possible Explanations of the Puzzle}

A possible explanation for the Forward Premium Puzzle often encountered in the literature is the existence of a risk premium in exchange rates. The risk premium can be regarded as an omitted variable in regression (7). However, it is difficult to reconcile this omitted-variable bias with the sign reversal, unless

\footnotetext{
${ }^{5}$ For example, if we assume that the spot exchange rate follows a geometric Brownian motion whose risk-neutral form is $\frac{\mathrm{d} S_{t}}{s_{t}}=\left(r-r^{*}\right) \mathrm{d} t+\sigma \mathrm{d} W_{t}$, then it is easy to show that $s_{T}-s_{t}=$ $\left(r-r^{*}\right)(T-t)-\sigma^{2}(T-t) / 2+\sigma\left(W_{T}-W_{t}\right)$, which gives $\alpha=-\sigma^{2}(T-t) / 2$.

${ }^{6}$ There is an entire avenue of research on UIP violation in both developed and emerging markets. See, e.g., Fama (1984), Engel (1996), Bansal \& Dahlquist (2000), Chinn \& Meredith (2004, 2005), Burnside et al. (2009) and Evans (2011).
} 
the premium negatively correlates with the interest-rate differential and varies over time significantly (see Fama, 1984). Even if we manage to explain the anomaly from a statistical point of view, it would still be very challenging to understand it economically. Namely, it would remain unclear which source of risk the investors are compensated for. The risk premium interpretation thus remains to be a futile attempt in explaining the Forward Premium Puzzle, at least to date. ${ }^{7}$ Other common views on the anomaly include questioning the general validity of the rational expectation hypothesis $(1),{ }^{8}$ examining the role of monetary policy, ${ }^{9}$ or exploring various econometric issues related to equation (7).

Another typical feature of most regressions given by equation (7) is the low $R^{2}$. This is another puzzling and counterintuitive property: the interest-rate differential should be, after all, the crucial exchange-rate fundamental. An alternative way to see the perplexing nature of this finding is to consider the differences in log price levels, i.e. the inflation differentials. Under purchasing power parity, the inflation differentials should be the fundamental driver of exchange-rate appreciation. As Fama \& Gibbons (1984) show, the inflation differentials are quite predictable. In addition, the interest-rate differentials may be regarded as expected inflation differentials. Hence, it is reasonable to expect that interest-rate differentials should explain much higher degree of variation in exchange rates than the one typically observed.

\section{Methodology}

To construct the explained variable in regression (7), we use the series of daily observations of EUR/RSD exchange rate between January 4, 2008 and July 17,2015 . The explanatory variable is obtained from BELIBOR and EURIBOR interbank rates for different maturities $\Delta t=T-t$. The available maturities were 1 week, 2 weeks, 1 month, 2 months, 3 months and 6 months. The exchange rate and BELIBOR data are available from the web service of the National Bank of Serbia. The data on EURIBOR rates are available from the web site of the Euribor Interbank Panel, www.euribor-rates.eu. Daily exchange rates are displayed in Figure 1, and the interbank rates for available

\footnotetext{
${ }^{7}$ See, for example, Bekaert \& Hodrick (1993), Bekaert (1995, 1996), Bekaert et al. (1997), Mark \& Wu (1998) and Graveline (2006).

${ }^{8}$ See Froot \& Frankel (1989), Lewis (1989), Chinn \& Frankel $(1994,2002)$ and Bacchetta \& van Wincoop $(2007,2010)$.

${ }^{9}$ See McCallum (1994), Clarida \& Waldman (2007) and Tambakis \& Tarashev (2012).

${ }^{10}$ See Moore (1994), Baillie \& Bollerslev (2000), Maynard \& Phillips (2001), Maynard (2003) and Villanueva (2005).
} 
Božović M., Talijan M.: The anomalous forward premium of EUR/RSD exchange rate

maturities in Figures 2 and 3. The corresponding summary statistics are given in Tables $1-3 .^{11}$

Figure 1. Evolution of daily EUR/RSD exchange rates

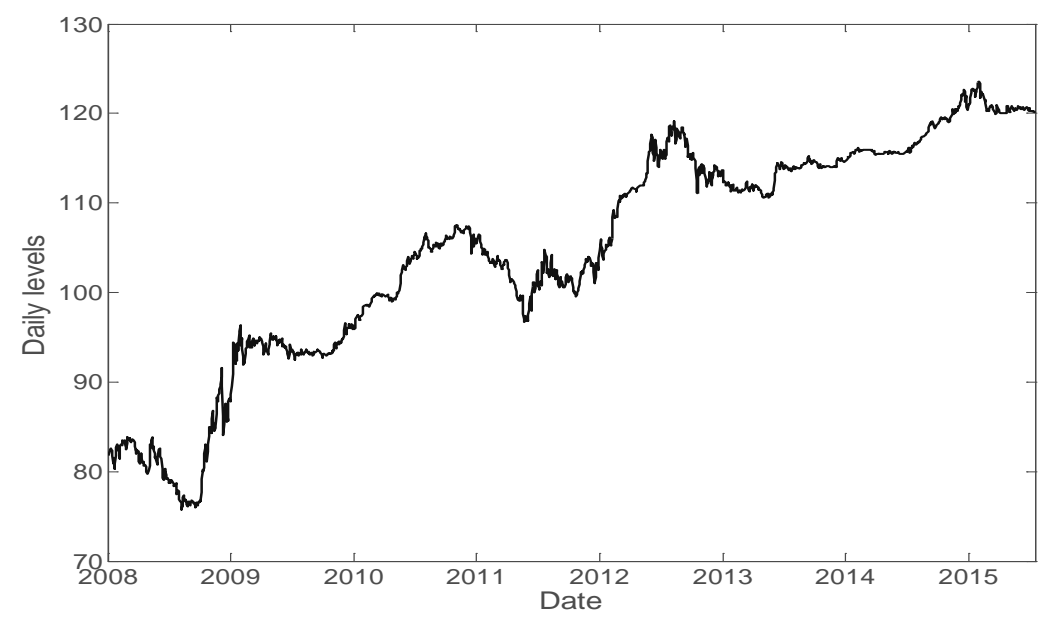

Source: National Bank of Serbia.

Figure 2. Evolution of daily BELIBOR rates

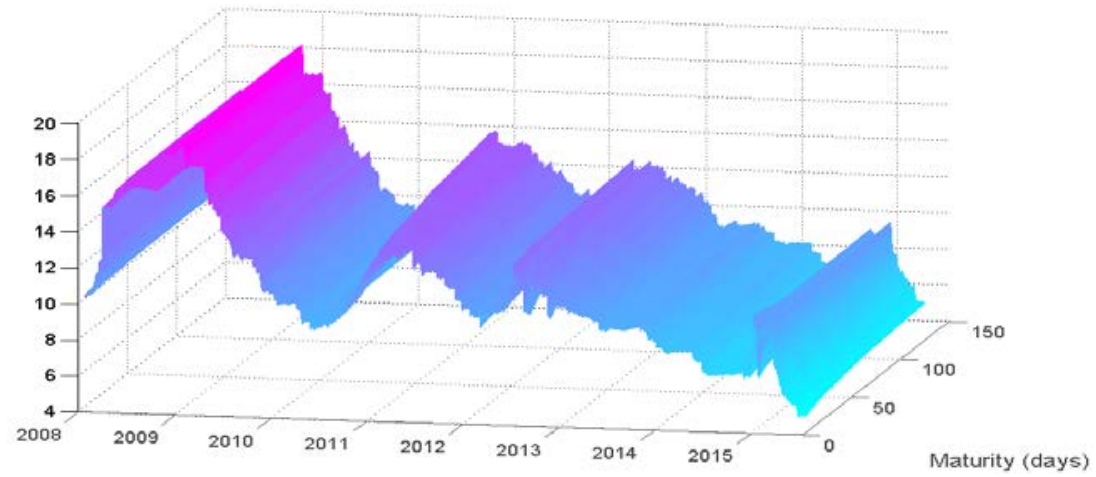

Source: National Bank of Serbia.

${ }^{11}$ From a purely theoretical standpoint, a better alternative would be to work with yields on Treasury securities instead of the interbank rates, since these instruments are available to a wider set of investors, including non-financial institutions and individuals, and hence could represent a better proxy for the "risk-free" assets. However, data on RSD-denominated Serbian Treasury bills and bonds from the secondary market are not available with daily frequency throughout the entire sample period. In addition, the secondary market for Serbian Treasury securities is very shallow and illiquid, so the results of regression (7) would carry additional noise originating from the liquidity and credit-risk premium that investors in, say, German Bunds require over Serbian Treasury instruments. 
Božović M., Talijan M.: The anomalous forward premium of EUR/RSD exchange rate

Figure 3. Evolution of daily EURIBOR rates

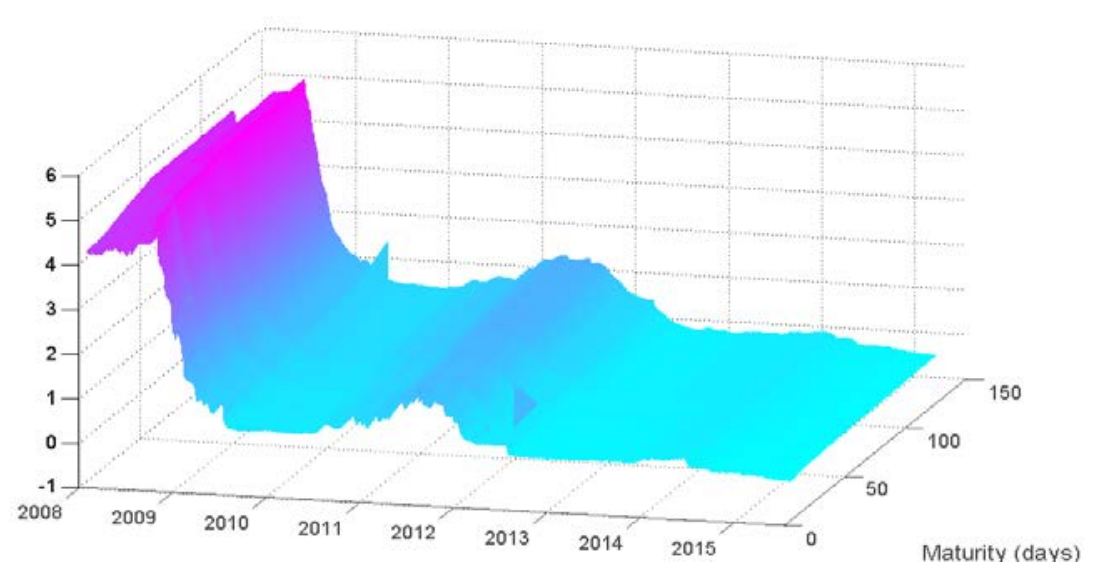

Source: Euribor Interbank Panel.

Table 1. Summary statistics for daily EUR/RSD exchange rates

\begin{tabular}{l|rrr}
\hline \hline Statistic & \multicolumn{1}{|c}{ Levels } & Daily changes & Log returns (\%) \\
\hline Mean & 104.6288 & 0.0202 & 0.0202 \\
Standard deviation & 12.3817 & 0.3763 & 0.3898 \\
Minimum & 75.7543 & -3.2217 & -3.6665 \\
Maximum & 123.5774 & 2.1318 & 2.4055 \\
Skewness & -0.6025 & -0.2470 & -0.2044 \\
Kurtosis & 2.4112 & 10.7484 & 13.2383 \\
\hline \hline
\end{tabular}

Source: Authors' calculations based on the data from the National Bank of Serbia.

Table 2. Summary statistics for daily BELIBOR rates (in percent)

\begin{tabular}{l|cccccc}
\hline \hline Statistic & 1 week & 2 weeks & 1 month & 2 months & 3 months & 6 months \\
\hline Mean & 11.0008 & 11.1149 & 11.3037 & 11.4573 & 11.6410 & 11.8797 \\
Standard & 3.1265 & 3.0909 & 3.0424 & 3.0012 & 2.9459 & 2.8894 \\
deviation & & & & & & \\
Minimum & 4.7400 & 4.9600 & 5.1800 & 5.3900 & 5.6200 & 5.8800 \\
Maximum & 18.9600 & 18.8800 & 18.9400 & 19.1500 & 19.1800 & 19.2300 \\
Skewness & 0.5826 & 0.5838 & 0.5497 & 0.5260 & 0.4921 & 0.4431 \\
Kurtosis & 2.8530 & 2.8405 & 2.8007 & 2.7896 & 2.7306 & 2.6460 \\
\hline \hline
\end{tabular}

Source: Authors' calculations based on the data from the National Bank of Serbia. 
Božović M., Talijan M.: The anomalous forward premium of EUR/RSD exchange rate

Table 3. Summary statistics for daily EURIBOR rates (in percent)

\begin{tabular}{l|rrrrrc}
\hline \hline Statistic & 1 week & 2 weeks & 1 month & 2 months & 3 months & 6 months \\
\hline Mean & 0.8862 & 0.9157 & 0.9904 & 1.0903 & 1.2020 & 1.3772 \\
Standard & 1.3135 & 1.3278 & 1.3667 & 1.4152 & 1.4474 & 1.4317 \\
deviation & & & & & & \\
Minimum & -0.1330 & -0.1180 & -0.0720 & -0.0390 & -0.0190 & 0.0480 \\
Maximum & 5.0200 & 5.0300 & 5.2000 & 5.2500 & 5.3900 & 5.4500 \\
Skewness & 1.8997 & 1.8725 & 1.8246 & 1.7933 & 1.7395 & 1.6424 \\
Kurtosis & 5.2301 & 5.1396 & 4.9860 & 4.8984 & 4.8012 & 4.6445 \\
\hline \hline
\end{tabular}

Source: Authors' calculations based on the data from the Euribor Interbank Panel.

We use the following form of regression (7):

$$
s_{t+\Delta t}-s_{t}=\alpha+\beta\left(r_{t, t+\Delta t}-r_{t, t+\Delta t}^{*}\right) \Delta t+\varepsilon_{t, t+\Delta t},
$$

where, as before, $s_{t}=\ln S_{t}$ for any $t$, and the following transformations to continuously compounded rates were made for the sake of mathematical consistency:

$$
\begin{aligned}
& r_{t, t+\Delta t}=\ln \left(1+R_{t, t+\Delta t}\right) \Delta t \\
& r_{t, t+\Delta t}^{*}=\ln \left(1+R_{t, t+\Delta t}^{*}\right) \Delta t .
\end{aligned}
$$

In equations (9), $R_{t, t+\Delta t}$ and $R_{t, t+\Delta t}^{*}$ represent the "raw" BELIBOR and EURIBOR rates (in decimals), respectively.

\section{Results and Discussion}

The regression (8) is ran separately for $\Delta t=1$ week, 2 weeks, 1 month, 2 months, 3 months and 6 months. The results of an ordinary least square estimation are summarised in Table 4. For each time horizon, the table shows the average log appreciation of the spot exchange rate, $s_{t+\Delta t}-s_{t}$, and the average log interest-rate differential, $\left(r_{t, t+\Delta t}-r_{t, t+\Delta t}^{*}\right) \Delta t$, both expressed in basis points. The estimates of $\alpha$ and $\beta$ coefficients are accompanied by their standard errors. One can immediately notice that both $\alpha$ and $\beta$ are insignificant for $\Delta t=1$ and 2 weeks. In addition, $\beta$ is also insignificant for $\Delta t=$ 1 month. In other words, interest-rate differential has absolutely no power to predict the changes in future spot rates for horizons up to one month. The coefficient $\alpha$ is significant and positive for $\Delta t=1$ month and above. The null hypothesis that $\beta=0$ can be rejected at 0.10 significance level for $\Delta t=2$ months, and for all reasonable significance levels for $\Delta t=3$ and 6 months. 
Božović M., Talijan M.: The anomalous forward premium of EUR/RSD exchange rate

Whenever $\beta$ turns out to be significant, it is negative, thus confirming the Forward Premium Puzzle for EUR/RSD exchange rate.

Table 4. Regression results

\begin{tabular}{|c|c|c|}
\hline $\begin{array}{l}1 \text { week } \\
\text { Average appreciation (in b.p.) } \\
\text { Average interest-rate differential (in b.p.) } \\
\alpha \\
\beta \\
R^{2} \\
\text { F-statistic } \\
\end{array}$ & $\begin{array}{r}0.08 \\
0.19 \\
0.0006 \\
0.1177 \\
0.0030 \\
0.0577 \\
\end{array}$ & $\begin{array}{l}(0.0010) \\
(0.4903)\end{array}$ \\
\hline $\begin{array}{l}2 \text { weeks } \\
\text { Average appreciation (in b.p.) } \\
\text { Average interest-rate differential (in b.p.) } \\
\alpha \\
\beta \\
R^{2} \\
\text { F-statistic }\end{array}$ & $\begin{array}{r}0.18 \\
0.38 \\
0.0019 \\
-0.0257 \\
0.0003 \\
0.0053 \\
\end{array}$ & $\begin{array}{l}(0.0014) \\
(0.3533)\end{array}$ \\
\hline $\begin{array}{l}1 \text { month } \\
\text { Average appreciation (in b.p.) } \\
\text { Average interest-rate differential (in b.p.) } \\
\alpha \\
\beta \\
R^{2} \\
\text { F-statistic }\end{array}$ & $\begin{array}{r}0.39 \\
0.77 \\
0.0062^{* \star \star} \\
-0.3029 \\
0.0656 \\
1.2486 \\
\end{array}$ & $\begin{array}{l}(0.0022) \\
(0.2724)\end{array}$ \\
\hline $\begin{array}{l}2 \text { months } \\
\text { Average appreciation (in b.p.) } \\
\text { Average interest-rate differential (in b.p.) } \\
\alpha \\
\beta \\
R^{2} \\
\text { F-statistic }\end{array}$ & $\begin{array}{c}0.79 \\
1.56 \\
0.0138^{* \star *} \\
-0.3733^{* \star} \\
0.1589 \\
3.0275^{* \star}\end{array}$ & $\begin{array}{l}(0.0034) \\
(0.2168)\end{array}$ \\
\hline $\begin{array}{l}3 \text { months } \\
\text { Average appreciation (in b.p.) } \\
\text { Average interest-rate differential (in b.p.) } \\
\alpha \\
\beta \\
R^{2} \\
\text { F-statistic }\end{array}$ & $\begin{array}{r}1.20 \\
2.36 \\
0.0275^{* * *} \\
-0.6569^{* * *} \\
0.6053^{\text {*** }} \\
11.5836^{*}\end{array}$ & $\begin{array}{l}(0.0047) \\
(0.1961)\end{array}$ \\
\hline $\begin{array}{l}6 \text { months } \\
\text { Average appreciation (in b.p.) } \\
\text { Average interest-rate differential (in b.p.) } \\
\alpha \\
\beta \\
R^{2} \\
\text { F-statistic }\end{array}$ & $\begin{array}{c}2.74 \\
5.01 \\
0.0534^{\star \star *} \\
-0.5201^{* \star \star} \\
0.6464 \\
12.3737^{\star \star \star}\end{array}$ & $\begin{array}{l}(0.0000) \\
(0.1530)\end{array}$ \\
\hline
\end{tabular}

Source: Authors' own estimates.

Standard errors are reported in parentheses.

${ }^{\star}-p$-value $<0.10 ;{ }^{* *}-p$-value $<0.05 ;{ }^{* \star *}-p$-value $<0.01$. 
The percent of variation in future spot rate appreciation explained by the interest-rate differential increases with time horizon. $R^{2}$ is above 0.60 for $\Delta t=$ 3 and 6 months. The regression model (8) fits the data progressively better: with the increase in time horizon, the joint significance increases as well, as $F$ statistic is going above its critical value at 0.05 significance level for $\Delta t=2,3$ and 6 months.

The predictive ability of the interest-rate differential can be visualised in the following way. Expectation of both sides of equation (8), conditionally on the information available at time $t$, is given by:

$$
\mathbb{E}_{t}\left(s_{t+\Delta t}\right)-s_{t}=\hat{\alpha}+\hat{\beta}\left(r_{t, t+\Delta t}-r_{t, t+\Delta t}^{*}\right) \Delta t,
$$

where $\hat{\alpha}$ and $\hat{\beta}$ are coefficient estimates from Table 4, for each time horizon $\Delta t$. Equation (10) thus establishes the relationship between average log future spot rate appreciation and average interest-rate differential. This is visualised in Figure 4 for each $\Delta t$. The blue lines represent the true realised averages of $\log$ future spot rate appreciation between $t$ and $t+\Delta t$, given by the left-hand side of equation (10). The red lines represent the right-hand side of equation (10). The conditional expectation $\mathbb{E}_{t}(\cdot)$ is computed as a moving-window arithmetic mean of all the daily values between $t$ and $t+\Delta t$.

The predictability of exchange rate appreciation by the interest-rate differential is very weak overall. However, it gradually improves with the time horizon, consistently with the increase in $R^{2}$. This can be seen, for instance, as appearance of a slight non-monotonic "pattern" of predicted average appreciation for $\Delta t=3$ and 6 months ahead (bottom two graphs in Figure 4).

Figure 4. Average future spot rate appreciation
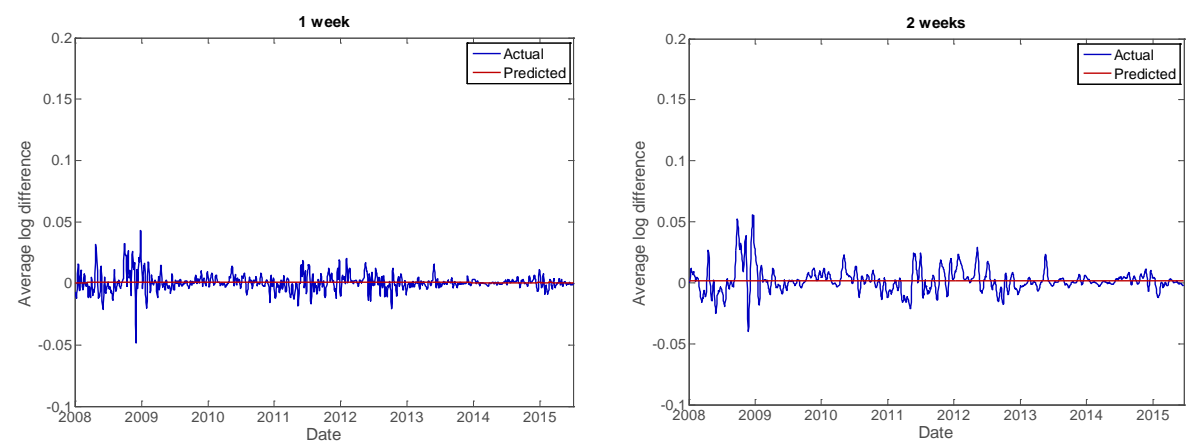
Božović M., Talijan M.: The anomalous forward premium of EUR/RSD exchange rate
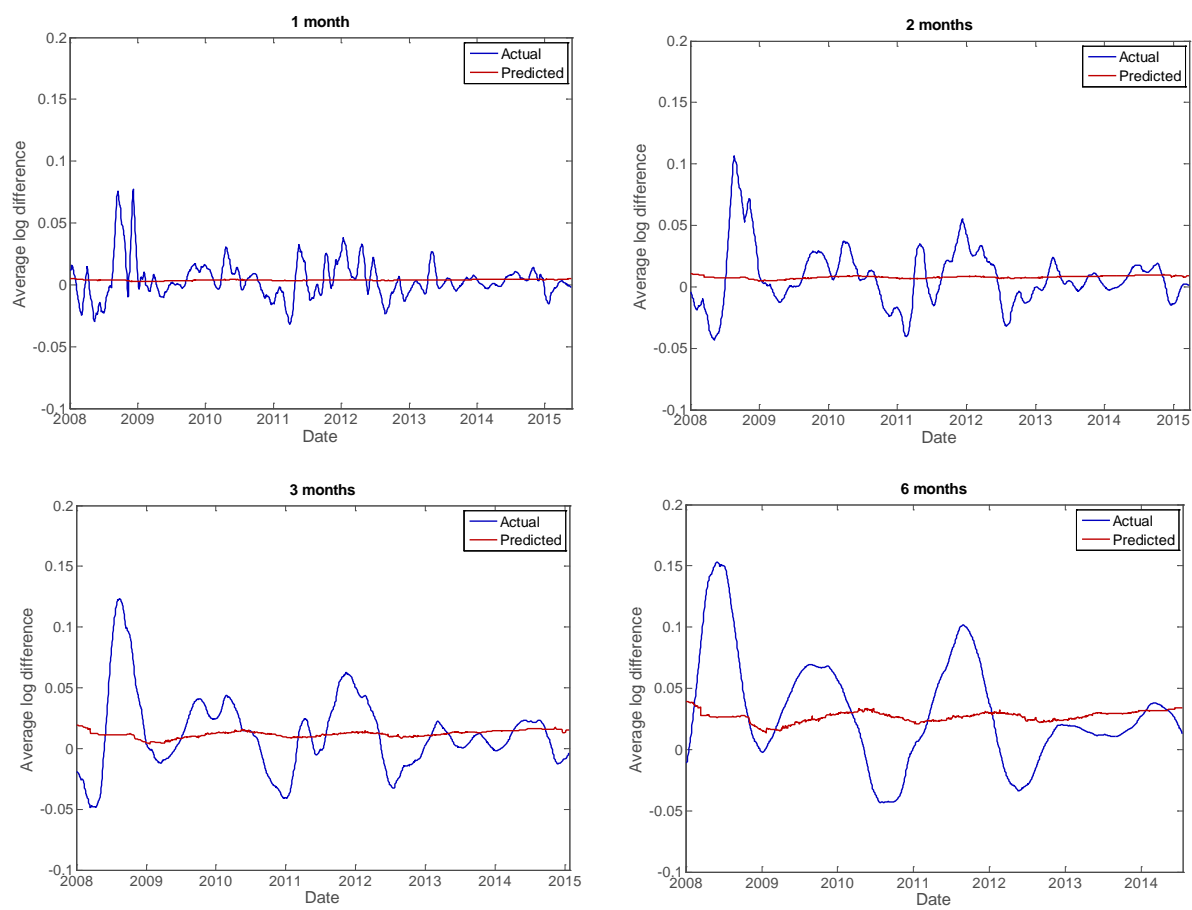

Source: Authors' own calculations.

Table 5. Test of uncovered interest-rate parity

\begin{tabular}{c|c}
\hline \hline 1 week & $-1.7996^{*+*}$ \\
$t$-statistic & 0.0360 \\
$p$-value & \\
\hline 2 weeks & $-2.9031^{*+*}$ \\
$t$-statistic & 0.0019 \\
$p$-value & \\
\hline -statistic & $-4.7822^{*+*}$ \\
$p$-value & 0.0000 \\
\hline 2 months & \\
$t$-statistic & $-6.3346^{*+*}$ \\
$p$-value & 0.0000 \\
\hline 3 months & \\
$t$-statistic & $-8.4504^{*+* *}$ \\
$p$-value & 0.0000 \\
\hline 6 months & $-9.9369^{*+*}$ \\
$t$-statistic & 0.0000 \\
$p$-value & \\
\hline \hline
\end{tabular}

Source: Authors' own estimates. 
Table 5 shows the results of the test for the null hypothesis that $\beta=1$. The uncovered interest-rate parity can be strongly rejected for all time horizons. This is not surprising given that the estimates of $\beta$ are either insignificant or negative in regression (8).

\section{Conclusion}

In sum, the paper studies the predictability of the EUR/RSD exchange rate by the differential of BELIBOR and EURIBOR interest rates. Aggregated daily observations between January 4, 2008 and July 17, 2015, with time horizons ranging from one week to six months, have been used. The results indicate the evidence of anomalous forward premium, which manifests in either insignificant or negative association between the exchange rate and the interest-rate differential. This is in stark contrast with the theoretical prediction that interest-rate differential should be one of the major exchange-rate fundamentals, having a positive relationship between the two variables.

Regression estimates imply that the average log exchange rate appreciation can be predicted through a linear relationship, to some extent, by the average interest-rate differential. This weak predictive power builds up with the time horizon. On the other hand, the hypothesis of uncovered interest-rate parity can be rejected for all time horizons. The absence of uncovered interest-rate parity is consistent with the detected anomaly, as well as many previous findings reported in the literature for different currency pairs.

To the best of our knowledge, this is the first paper that reports the presence of the Forward Premium Puzzle for EUR/RSD exchange rate. The findings are also consistent with the violations of the uncovered interest rate parity for the EUR/RSD pair previously reported in the literature (see Petrović, 2013a,b). Thus, the puzzle may not be restricted to developed financial markets, as some authors suggest. The results of this paper add to the increasing body of empirical evidence for this peculiar anomaly, which seems to persist in the global foreign exchange market.

\section{References}

Bacchetta, P., \& van Wincoop, E. (2007). Random walk expectations and the forward discount puzzle. American Economic Review, 97, 346-350.

Bacchetta, P., \& van Wincoop, E. (2010). Infrequent portfolio decisions: A solution to the forward discount puzzle. American Economic Review, 100, 870-904.

Baillie, R.T., \& Bollerslev, T. (2000). The Forward Premium Anomaly Is Not As Bad As You Think. Journal of International Money and Finance, 19, 471-488. 
Bansal, R., \& Dahlquist, M. (2000). The Forward Premium Puzzle: Different Tales from Developed and Emerging Economies. Journal of International Economics, 51, 115-144.

Bekaert, G., \& Hodrick, R.J. (1993). On Biases in the Measurement of Foreign Exchange Risk Premiums. Journal of International Money and Finance, 12, 115138.

Bekaert, G. (1995). The Time-Variation of Expected Returns and Volatility in Foreign Exchange Markets. Journal of Business and Economic Statistics, 13, 397-408.

Bekaert, G. (1996). The Time-Variation of Risk and Return in Foreign Exchange Markets: A General Equilibrium Perspective. Review of Financial Studies, 9, 427-470.

Bekaert, G., Hodrick, R.J., \& Marshall, D.A. (1997). The Implications of First-Order Risk Aversion for asset Market Risk Premiums. Journal of Monetary Economics, 40, 467-509.

Boudoukh, J., Richardson, M., \& Whitelaw, R.F. (2013). New evidence on the forward premium puzzle. Working paper. Retrieved from http://pages.stern.nyu.edu/ rwhitela/papers/FwdPremPuzz_2013_06_12.pdf

Burnside, C., Eichenbaum, M., \& Rebelo, S. (2009). The returns to currency speculation in emerging markets. American Economic Review, 97, 333-338.

Cheung, Y.W., Chinn, M., \& Pascual, A.G. (2005). Empirical Exchange Rate Models of the Nineties: Are Any Fit to Survive.Journal of International Money and Finance, 24, 1150-1175.

Chin, M.D., \& Meredith, G. (2004). Monetary Policy and Long-Horizon Uncovered Interest Parity. IMF Staff Paper, 409-430.

Chin, M.D., \& Meredith, G. (2005). Testing uncovered interest parity at short and long horizons during the post-Bretton Woods era. Working Paper 11077. Retrieved from http://www.ssc.wisc.edu/ mchinn/uip_empr2005.pdf

Chinn, M., \& Frankel, J. (1994). Patterns in Exchange Rate Forecasts for Twenty-Five Currencies. Journal of Money, Credit and Banking, 26(4), 26(4): 759. doi:10.2307/2077945

Chinn, M.D., \& Frankel, J.A. (2002). Survey Data on Exchange Rate Expectations: More Currencies, More Horizons, More Tests. In W. Allen \& D. Dickinson (Eds.), Monetary Policy, Capital Flows and Financial Market Developments in the Era of Financial Globalisation: Essays in Honour of Max Fry. (pp. 145-167). London: Routledge.

Clarida, R. \& Waldman, D. (2007) Is Bad News About Inflation Good News for the Exchange Rate? Working Paper No. 13010, National Bureau of Economic Research.

Engel, C., \& West, K.D. (2005). Exchange Rates and Fundamentals. Journal of Political Economy, 113, 485-517.

Engel, C. (1996). The Forward Discount Anomaly and the Risk Premium: A Survey of Recent Evidence. Journal of Empirical Finance, 3, 123-192.

Evans, M. (2011). Exchange Rate Dynamics. Princeton, NJ: Princeton University Press.

Fama, E.F., \& Gibbons, M. (1984). A Comparison of Inflation Forecasts. Journal of Monetary Economics, 13, 327-348.

Fama, E.F. (1984). Forward and Spot Exchange Rates. Journal of Monetary Economics, 14, 319-338. 
Božović M., Talijan M.: The anomalous forward premium of EUR/RSD exchange rate

Froot, K.A., \& Frankel, J.A. (1989). Forward Discount Bias: Is it an Exchange Risk Premium. Quarterly Journal of Economics, 104(1), 104(1): 139. doi:10.2307/2937838

Graveline, J.J. (2006). Exchange Rate Volatility and the Forward Premium Anomaly. working paper. Retrieved from http://www.nccrfinrisk.uzh.ch/media/pdf/GravelineJMP.pdf

Hodrick, R.J. (1987). The Empirical Evidence on the Efficiency of Forward and Futures Foreign Exchange Markets. Switzerland: Harwood Academic Publishers, Chur.

Hodrick, R. J. (1987) The Empirical Evidence on the Efficiency of Forward and Futures Foreign Exchange Markets. Harwood Academic Publishers, Chur, Switzerland.

Hodrick, R.J. (2000). International Financial Management. Englewood Cliffs, NJ: Prentice-Hall..

Lewis, K.K. (1989). Changing Beliefs and Systematic Rational Forecast Errors with Evidence from Foreign Exchange.American Economic Review, 79(4), 621-636.

Mark, N.C., \& Wu, Y. (1998). Rethinking Deviations from Uncovered Interest Rate Parity: The Role of Covariance Risk and Noise. Economic Journal, 108, 16861706.

Maynard, A., \& Phillips, P.C.B. (2001). Rethinking an old empirical puzzle: Econometric evidence on the forward discount anomaly. Journal of Applied Econometrics, 16(6), 671-708. 16(6): 671-708. doi:10.1002/jae.624

Maynard, A. (2003). Testing for Forward-rate Unbiasedness on Regression in Levels and in Returns. Review of Economics and Statistics, 85(2), 313-327.

McCallum, B.T. (1994). A Reconsideration of the Uncovered Interest Parity Relationship. Journal of Monetary Economics,33, 105-132.

Meese, R.A., \& Rogoff, K.S. (1983). Empirical Exchange Rate Models of the Seventies: Do They Fit Out of Sample. Journal of International Economics, 14(12), 3-24.

Meese, R.A., \& Rogoff, K.S. (1983). The Out-of-Sample Failure of Empirical Exchange Rate Models: Sampling Error or Mis-specification. In J. Frenkel (Ed.), Exchange Rates and International Macroeconomics. Chicago: NBER and University of Chicago Press.

Meese, R.A., \& Rogoff, K.S. (1988). Was it Real?, The Exchange Rate-Interest Differential Relation over the Modern Floating Rate Period. Journal of Finance, 43, 923-948.

Mengistu, A. (2014) Testing the UIP Hypothesis-Using Data from Partially Dollarized Developing Countries. International Journal of Economics and Finance, 6(4), 135-146. doi: http://dx.doi.org/10.5539/ijef.v6n4p135.

Meredith, G., \& Chinn, M.D. (1998). Long-horizon uncovered interest rate parity. working paper, No. 6797. Retrieved from http://www.eco.unibs.it/ vassalli/Longhorizon\%20UIP.pdf

Moore, M.J. (1994). Testing for Unbiasedness in Forward Markets. The Manchester School, 62, 67-78. Supplement.

Petrović, P.M. (2013a) Testing of empirical grounds for theoretical models of real exchange rate: Research of real exchange rate between RSD and Euro. Industrija, 41(1), 99-115. doi:10.5937/industrija41-3522.

Petrović, P.M. (2013b) Testing of real exchange rate - real interest rate differential relationship in Serbia-EMU case. Industrija, 41(4), 111-125. doi: 10.5937/industrija41-4242. 
Božović M., Talijan M.: The anomalous forward premium of EUR/RSD exchange rate

Rossi, B. (2013). Exchange Rate Predictability. Journal of Economic Literature, 51(4), 1063-1119. doi: 10.1257/jel.51.4.1063.

Tambakis, D.N., \& Tarashev, N.A. (2012). Systematic Monetary Policy and the Forward Premium Puzzle. Working Paper 396. Retrieved from http://www.bis.org/publ/work396.pdf

Villanueva, O.M. (2005). FX Dynamics, Limited Participation, and the Forward Bias Anomaly. The Financial Review, 10, 67-93.

Wu, Y., \& Zhang, H. (1996). Asymmetry in Forward Exchange Rate Bias: A Puzzling Result. Economics Letters, 50, 407-411. 